\title{
THE MEDIATING ROLES OF PRO-COMMITMENT TO LEARNING AND ADAPTABILITY TO TECHNOLOGICAL CHANGE: PROFESSIONAL EXPERIENCE PORTFOLIO TOWARD EMPLOYEE PERFORMANCE
}

\author{
Fitri WULANDARI ${ }^{\circledR}{ }^{*}$, Christantius DWIATMADJA ${ }^{2}$, IMRONUDIN ${ }^{3}$ \\ ${ }^{1}$ Institut Agama Islam Negeri (IAIN) Surakarta, Sukoharjo, Indonesia \\ ${ }^{2}$ Satya Wacana Christian University, Salatiga, Indonesia \\ ${ }^{3}$ Universitas Muhamadiyah Surakarta, Sukoharjo, Indonesia
}

Received 6 May 2020; accepted 15 July 2020

\begin{abstract}
To overcome the problem of declining performance, organizations need a variety of professional experience portfolio and strong pro-commitment to learning in addition to the need for employees to adapt to various changes, especially technological changes. Adopting the role of organizational learning theory and human capital, this study aims to analyse the pro-commitment to learning and adaptability to change whether it is able to mediate the influence of the professional experience portfolio on employee performance. The sample of this research consists of the managers and supervisors at PT POS Region VI in Indonesia. Using stratified random sampling, this research sample involves 223 participants. Research data were analysed using Equation Model (SEM). The results show that there are positive and significant influences of all of the variables studied, except for the direct effect of the professional experience portfolio on employee performance. Thus, the role of pro-commitment to learning mediation and adaptability to technological change are fully mediating variables on the effect of professional experience portfolio toward employee performance. It takes an appropriate linear and crossfield experience for managers and supervisors to increase innovative new opportunities through strength of commitment to learning and readiness in encountering technological changes so that companies can survive amidst sharp competition.
\end{abstract}

Keywords: experience, pro-commitment to learning, adaptability, performance.

JEL Classification: M51, M53, M54.

\section{Introduction}

In the era of globalization, the ever-changing business environment, with more stringent competition and increasing consumer demand particularly over the last few years, has shifted the issues related to employee competency significantly. The key to a company's success is the presence of employees who are competent and flexible in facing changes Brzeziński and Bąk (2015). According to Kumar et al. (2013), an organization needs to be able to successfully adapt to market changes. This successful adaptation depends on how ready employees are to face changes.

Adaptation is needed to cope with task changes which are sometimes unpredictable, and which may be seen as unusual as a result of unexpected changes (Omar \& Noordin, 2016). Employees are required to develop new skills, beyond the basic skills which tend to be static, because the company has to face market, knowledge and skills changes. Tien et al. (2012) state that the ability to adapt is an individual's ability to change without great difficulty and be able to fit into new conditions. Adaptation means continuous change in response to new situations. At this time of the ubiquitous use of computers, the internet, and rapid development of artificial intelligence, the work environment is an ever-changing one in which information technology plays a vital role in strengthening a company's competitiveness. Companies are trying to increase the level of investment in them because information technology is not only acting to reduce costs, but also to enhance business performance (Lee et al., 2016; Razak et al., 2015).

The research gap in this research is the professional experience portfolio towards employee performance. The term "Professional" carries the meaning of having a special skill or expertise achieved through formal and long-term training. The professional experience portfolio has an essential role in forcing employees to cope with changes. The influence of varied employee experience in improving employee performance has been investigated in previous

*Corresponding author. E-mail: fitri.wulandari@iain-surakarta.ac.id 
research to show that the professional experience portfolio will improve employee performance (Borgia et al., 2014; Mahony et al., 2012; Pousa et al., 2017; Rong et al., 2012). Previous work experience has a major factor in increasing employee performance (Mahony et al., 2012). However, how employees with varied prior work experience will be able to improve employee performance requires further investigation since not all employees can draw benefit from their past work experience to improve performance.

Various previous work experiences have an effect on the readiness of employees to deal with organizational change. Employees with limited work experience tend to behave in a reactive manner and show emotion when facing change. Reactive and emotional behavior is indicated by various behaviors that cause fatigue, frustration or stress in facing changes, and a tendency to act negatively. In contrast, if employees have had a variety of work experiences and tend to regard change as part of a process which can provide an arena for learning, exploration of existing potential, and transference of experience, they also tend to be more positive in their thinking toward the changes which provides new energy for improvement (Stensaker \& Meyer, 2012). To improve employee performance, procommitment to learning is needed, in addition to adaptability to technological changes. This is in accordance with Maurer and Weiss (2010) view that continuous learning is an important part of successful work. The purpose of this study are threefold. Firstly, to examine the role of the quality of professional experience on employee performance at the individual level. Secondly, to examine the role of pro-commitment to learning mediation and adaptation to technological change in improving employee performance. Thirdly, to examine in more depth the role of organizational learning theory and human capital theory to support novelty research.

\section{Theoretical review and hypothesis development}

\subsection{The effect of adaptability to technological change on employee performance}

The concept of adaptability is derived from the theory of human capital. Human capital is related to the abilities, knowledge, skills, and qualifications possessed by individuals (Chang \& Chen, 2011; Gonzalez \& de Melo, 2018). Whereas Ruíz et al. (2016) explain that human capital is competence, knowledge, social attributes and personality, including creativity, manifested in the ability to do work. Employee competence is a significant challenge to consider in individual competence and as part of the organization's core capability (Mandal, 2017). Knowing the manager's skills and competencies means knowing the ways an organization strives to achieve its goals (Muafi et al., 2018). Employee competence is measured based on an increase in the skills to understand, communicate with, motivate and support other employees, individually or in a team. Adaptability is part of an individual's competency in processing and adjusting him/herself to any changes.

In service companies, competitiveness strengths are very dependent on the technology that the company uses in providing fast and safe services. However, what is more important is the capability of human resources in adapting to and performing well amidst technological changes. This is in line with research conducted by (Jabbouri et al., 2016; Park \& Koh, 2017) which state that the ability of employees to meet the demands of change will increase employee performance. The research by Park and Koh (2017) concluded that rapid technological change is a key element in persuading customers to buy a particular product because technology produces better and cheaper products. As Lee et al. (2016) found, wireless technology is most significant in stimulating business profit. According to research conducted by Jabbouri et al. (2016), investment in information technology positively impacts company performance. The work of Bolatan et al. (2016) shows that technology transfer is correlated with the level of readiness in the environment, basic knowledge and willingness to learn in the business context. Research conducted by He (2014) shows that technological change adaptation increases competitive advantage.

H1: The higher the adaptation capability to technological change is, the higher the employee performance will be.

\subsection{The effect of pro-commitment to learning towards adaptation capability to technological change and employee performance}

The concept of renewal of pro-commitment to learning is adopted from the theory of organizational learning developed by Argyris and Schon (1978) and the theory of personal initiative by Glaub et al. (2014). Organizational learning is defined as a creative process of dynamic knowledge that is intended to develop human resources and contribute to organizational performance (V. Saadat \& Z. Saadat, 2016). Organizational learning is an important supporting factor that stimulates superior organizational performance because it involves learning new knowledge and changing behaviors. It stimulates business superiority because the organization learns faster than its competitors (Eshlaghy et al., 2011).

Organizational learning is a process that involves continuous cognitive and behavioral changes in employees (Argote, 2011). Organizational learning is a mechanism where individuals in an organization keep on learning, to build individual knowledge repositories within the organization so that the learning process is maintained. The specific knowledge of an individual in the organization is accessible to any member of the organization. Hence, when that individual leaves the organization, his/her knowledge will remain in various repositories or memories through routines, social networking and the organization's memory system (Zappa \& Robins, 2015). The findings of the research conducted by Tajeddini (2016) show that learning and innovation orientations lead to better 
performance of public organizations. More specifically, the results show that the orientation towards learning and innovation brings these organizations to a higher level in terms of service speed, cost improvement, public trust and performance. According to a test on the effect of proactive personality on employee performance conducted by Buil et al. (2018), a proactive personality is an important factor in career success. In general, this finding is strengthened by the prior research: an employee is more likely to have a successful career if she/he has a proactive personality.

$\mathrm{H} 2$ : The higher the pro-commitment to learning is, the higher the adaptation capability to technological change will be;

H3: The higher the pro-commitment to learning is, the higher the employee performance will be.

\subsection{The effect of professional experience portfolio on adaptation capability to technological change, pro-commitment to learning and employee performance}

According to Bazin and Aubert-Tarby (2013), a profession is a bunch of organized working experiences. An experience portfolio is a summary of an employee's experiences, both professional and social. Professional experience portfolio in this research refers to the sum of an employee's experiences in activities which are both in line and not in line with their current jobs that enable employees to acquire more knowledge, improve the skills needed in their present jobs and prepare them for their future career. Work experience is defined as the number of inter-departmental shifts and work experience in different departments.

Research conducted by Razak et al. (2015) on the factors that affect the success of employees in using information technology showed that employee skill together with strong motivation pushed them to work faster and smarter in adapting to more complex information technologies. Research by Gulfi et al. (2015) shows that professional experience stimulates a more effective and efficient system change. This finding is in accordance with Poon and Brownlow (2014) which showed that professional experience in property businesses stimulates the ability to communicate using digital technologies, and experience in operating digital technologies increases the level of practical experience and knowledge about international properties which in turn stimulates these professionals. Woo (2018) explains that new $\mathrm{CEO}$ multi-organizational experiences are positively related to acquisition performance. The multi-organizational experience in leading acquisitions further increases the flexibility and agility of the CEO to face various challenges. The more employees with linear experience a company has, the greater the chance the company has to adapt to changes.

$\mathrm{H} 4$ : the higher the professional experience portfolio is, the higher the adaptability to technological change will be;

H5: the higher the professional experience portfolio is, the higher the pro-commitment to learning will be;
H6: the higher the professional experience portfolio is, the higher the employee performance will be.

\section{Methodology}

\subsection{Data collection and sample}

The object of this research is the managers and middle managers of PT POS Region VI Central Java and Istimewa Region Yogyakarta (DIY). The Central Java region includes the areas of Surakarta, Sragen, Karanganyar, Wonogiri, Klaten, Sukoharjo, Boyolali, Salatiga, Magelang, Purwokerto, Cilacap, Semarang, Ungaran, Pati, Demak and Kudus. While the Yogyakarta region includes Bantul and Sleman. Because the population studied involves different levels and each level has its own characteristics, this study uses stratified random sampling (Hair et al., 2010). Furthermore, this study chose disproportional random sampling because of the representation of a large sample that needed more attention (for example, a POS office with type $\mathrm{B}$ received more attention than type $\mathrm{C}, \mathrm{D}$ or $\mathrm{E}$ because type $\mathrm{B}$ have the larger number of employees).

To anticipate a low response rate, this study distributes 300 questionnaires in the hope that returning questionnaires can meet the specified sample size. Of the 300 questionnaires distributed, the number of questionnaires returned was 230 questionnaires, and there were 7 questionnaires declared ineligible so that the proper questionnaires used in this study amounted to 223 because those number have satisfied required sample for Maximum Likelihood Estimation (MLE) (Hair et al., 2010). After testing the normality of the data, abnormal data was found. Then the outlier data was excluded so that the sample is reduced to 158 respondents.

\subsection{Measurement of scale}

A professional experience portfolio (Bazin \& Aubert-Tarby, 2013; Khojamli et al., 2014) is a summary of employee work experience, like linear work experience, and inclusive of various work experience and cross-field experience. Pro-commitment to learning (Brzeziński \& Bąk, 2015; Eshlaghy et al., 2011; Maurer \& Weiss, 2010) is the commitment of employees to learn. In relation to commitment to learning, a good employee is one who continuously strives to learn and understand customer needs, actively improves her/his skills to create new opportunities, actively makes innovations on products and processes, and endeavors to exceed competitors. Adaptability to technological change (Park \& Koh, 2017; Razak et al., 2015; Tippins \& Sohi, 2003) is the capability to adapt to any technological changes, to overcome resistance, to proactively adjust to technological changes inclusive of planned changes in data communication and information systems, for the purpose of meeting the company's requirements related to technological change. Employee performance (Nguyen et al., 2019; Pudjiarti \& Hutomo, 2020; Samnani et al., 2013) is the comparison between real achievement 
and the standard speed and punctuality in finishing a task, giving constructive suggestions related to the service to consumers or the main contracts, meeting required targets, and finishing the task according to the set standards.

\subsection{The data analysis}

In this study each variable was measured using a Likert scale where number 1 indicates strongly disagree until number 10 which indicates strongly agree. Then the data were analyzed with Structural Equation Model (SEM) with AMOS version 21.

\section{Result}

\subsection{Reliability and validity}

The result of the construct validity value testing in Table 1 shows that the professional experience portfolio, procommitment to learning, adaptability to technological change and employee performance constructs were based on the statistic cut off; the Composite Reliability (CR) are more than 0.7, the Average Variance Extract (AVE) are more than 0.7 , and the loading factors or Discriminant Validity (DV) are more than 0.7 . The result of validity test shows that standardized loading estimates is $>0.7$ which indicate that there is high convergent validity (Hair et al. 2010). The reliability of the instruments is tested the Average Variance Extract (AVE) are more than 0.7, The detail of the reliability values are as follow; 0.900 for professional experience portfolio, 0.916 for pro-commitment to learning, 0.908 for adaptability to technological change, 0.924 for employee performance. Finally, the KMO (Kaiser Meyer-Ohlin) test is used to test the suitability of the data with and the result is significant because $\mathrm{p}<0.05$.

Table 1. Standardized loading factor, composite reliability and average variance extract

\begin{tabular}{|c|c|c|c|c|c|c|}
\hline No & Variable & Items & $\begin{array}{l}\text { Stan- } \\
\text { dardi- } \\
\text { zed } \\
\text { Loading } \\
\text { Factor }\end{array}$ & \begin{tabular}{|c|} 
Com- \\
posite \\
Reli- \\
ability \\
(CR)
\end{tabular} & AVE & $\begin{array}{c}\text { KMO } \\
\text { Bartlett's } \\
\text { Test }\end{array}$ \\
\hline 1 & $\begin{array}{l}\text { Profe- } \\
\text { ssional } \\
\text { experience } \\
\text { portfolio }\end{array}$ & $\begin{array}{l}\text { PEP1 } \\
\text { PEP2 } \\
\text { PEP3 }\end{array}$ & $\begin{array}{l}0.890 \\
0.820 \\
0.890\end{array}$ & 0.900 & 0.752 & $443.531^{* *}$ \\
\hline 2 & $\begin{array}{l}\text { Pro- } \\
\text { commit- } \\
\text { ment to } \\
\text { learning }\end{array}$ & $\begin{array}{l}\text { PCL1 } \\
\text { PCL2 } \\
\text { PCL3 } \\
\text { PCL4 }\end{array}$ & $\begin{array}{l}0.890 \\
0.890 \\
0.810 \\
0.830 \\
\end{array}$ & 0.916 & 0.732 & $293.606^{* *}$ \\
\hline 3 & $\begin{array}{l}\text { Adapt- } \\
\text { ability to } \\
\text { techno- } \\
\text { logical } \\
\text { change }\end{array}$ & $\begin{array}{l}\text { ATC1 } \\
\text { ATC2 } \\
\text { ATC3 } \\
\text { ATC4 }\end{array}$ & $\begin{array}{l}0.780 \\
0.880 \\
0.820 \\
0.890\end{array}$ & 0.908 & 0.712 & $447.042^{\star *}$ \\
\hline 4 & $\begin{array}{l}\text { Employee } \\
\text { perfor- } \\
\text { mance }\end{array}$ & $\begin{array}{l}\text { EP1 } \\
\text { EP2 } \\
\text { EP3 } \\
\text { EP4 }\end{array}$ & $\begin{array}{l}0.870 \\
0.880 \\
0.860 \\
0.860\end{array}$ & 0.924 & 0.753 & $465.680^{* *}$ \\
\hline
\end{tabular}

Note: ${ }^{\star} \mathrm{p}<.05,{ }^{\star *} \mathrm{p}<.01$.

\subsection{Descriptive statistic, correlations and characteristic of respondents}

The results of the statistical test on mean, standard deviation, and matrix correlation between professional experience portfolio, pro-commitment to learning, adaptation capability to technological change, and employee performance constructs can be seen in Table 2 .

Table 2. Descriptive statistic and correlations

\begin{tabular}{|c|c|c|c|c|c|c|}
\hline & Mean & $\begin{array}{c}\text { Standard } \\
\text { Deviation }\end{array}$ & 1 & 2 & 3 & 4 \\
\hline $\begin{array}{l}\text { Pro-com- } \\
\text { mitment } \\
\text { to } \\
\text { learning }\end{array}$ & 32.86 & 2.927 & 1.000 & & & \\
\hline $\begin{array}{l}\text { Professio- } \\
\text { nal expe- } \\
\text { rience } \\
\text { portfolio }\end{array}$ & 24.06 & 2.188 & $.376^{\star *}$ & 1.000 & & \\
\hline $\begin{array}{l}\text { Adapt- } \\
\text { ability to } \\
\text { techno- } \\
\text { logical } \\
\text { change }\end{array}$ & 32.37 & 2.927 & $.423^{\star *}$ & $.816^{\star *}$ & 1.000 & \\
\hline $\begin{array}{l}\text { Employee } \\
\text { perfor- } \\
\text { mance }\end{array}$ & 32.83 & 2.913 & $.425^{\star *}$ & $.747^{\star *}$ & $.813^{\star *}$ & 1.000 \\
\hline
\end{tabular}

Note: ${ }^{\star} \mathrm{p}<.05 ;{ }^{\star *} \mathrm{p}<.01$.

The results show that the highest mean value is the pro-commitment to learning variable and the lowest mean value is the professional experience portfolio. Meanwhile, the standard deviation shows that the highest standard deviation is the pro-commitment to learning variable and the lowest standard deviation value is the professional experience portfolio variable. The results show that there is a positive correlation between the commitment to learning and the professional experience of the portfolio $(r=$ $.376, \mathrm{p}<.01)$, Adaptability to technological change $(\mathrm{r}=$ 423, $\mathrm{p}<.01)$, Employee performance $(\mathrm{r}=.425, \mathrm{p}<.01)$, Adaptability to technological change was correlated to professional experience portfolio $(\mathrm{r}=.816, \mathrm{p}<.01)$, employee performance was correlated to professional experience portfolio $(r=.747, \mathrm{p}<.01)$, employee performance was correlated to adaptability to technological change $(\mathrm{r}=$ $.813, \mathrm{p}<.01)$.

Based on the data indicated in Table 3, it is known that the number of respondents used in this study were 223 respondents consisting of $66.4 \%$ male respondents and $33.6 \%$ female respondents. The distribution based on the most education is senior high school amounting to $49.8 \%$ and the least is postgraduate which amounts to $3.1 \%$. From the position point of view, in this study respondents with managerial positions had the highest number which was $51.6 \%$ and the least position was strategic staff which was $9 \%$. While from work experience, the most experience is over 20 years with a total of $57.4 \%$. 
Table 3. Characteristic of respondents

\begin{tabular}{|c|c|c|}
\hline Characteristic & Number & Percentage \\
\hline \multicolumn{3}{|c|}{ GENDER } \\
\hline Male & 148 & $66.4 \%$ \\
\hline Female & 75 & $33.6 \%$ \\
\hline \multicolumn{3}{|c|}{ EDUCATION } \\
\hline Senior High School & 111 & $49.8 \%$ \\
\hline DIPLOMA & 13 & $5.8 \%$ \\
\hline Undergraduate & 92 & $41.3 \%$ \\
\hline Postgraduate & 7 & $3.1 \%$ \\
\hline \multicolumn{3}{|c|}{ JOB } \\
\hline Strategic Staff & 2 & $9 \%$ \\
\hline Supervisor & 106 & $47.5 \%$ \\
\hline Manager & 115 & $51.6 \%$ \\
\hline \multicolumn{3}{|c|}{ WORK EXPERIENCE } \\
\hline$<5$ years & 14 & $6.3 \%$ \\
\hline $6-10$ years & 45 & $20.2 \%$ \\
\hline $11-15$ years & 20 & $9.0 \%$ \\
\hline Years & 16 & $7.2 \%$ \\
\hline$>21$ years & 128 & $57.4 \%$ \\
\hline \multicolumn{3}{|c|}{ AREA/PROVINCES } \\
\hline Central Java & 16 & $89 \%$ \\
\hline $\begin{array}{l}\text { Daerah Istimewa } \\
\text { Yogyakarta }\end{array}$ & 2 & $11 \%$ \\
\hline
\end{tabular}

\subsection{Hypothesis testing and Sobel test}

The results of AMOS 21, indicated in Figure 1, shows that the value of statistic chi-Square is 154.977 which means the model is not yet fit because the chi-square statistic > of the chi-square table. Since the chi-square value is very conservative and depends on the large number of samples, it can cause type II errors (reject the correct model) so it is advisable to look at other goodness of fit indices (Hooper et al., 2008). However, because the number of samples used is large ( $>200)$, the chi-square value can be ignored. Other test results indicate that the value of CMIN/df is $1.823 \leq 2.00$ (Fit); the TLI/Tuckle Lewis Index score is $0.962>0.90$ (Fit), the AGFI/Adjusted Goodness of Fit score is $0.841<0.90$ (Medium), the CFI/ Comparative Fit Index score is $0.887<0.90$ (Medium), the CFI is $0.969>$ 0.09 (Fit); and the RMSEA score is $0.072<0.08$ (Fit). It indicates that these scores have suited the predetermined cut-off.

- H1: there is an effect of adaptation capability to technological change towards employee performance. Table 4 shows the path of structural models that explain the relationship between adaptability to technological change towards employee performance. The structural path findings indicate that there is a significant and positive relationship between adaptability to technological change and employee performance $(\mathrm{t}=2.762>1.96)$ with significant value $(0.00<0.01)$. So, the first hypothesis is accepted.

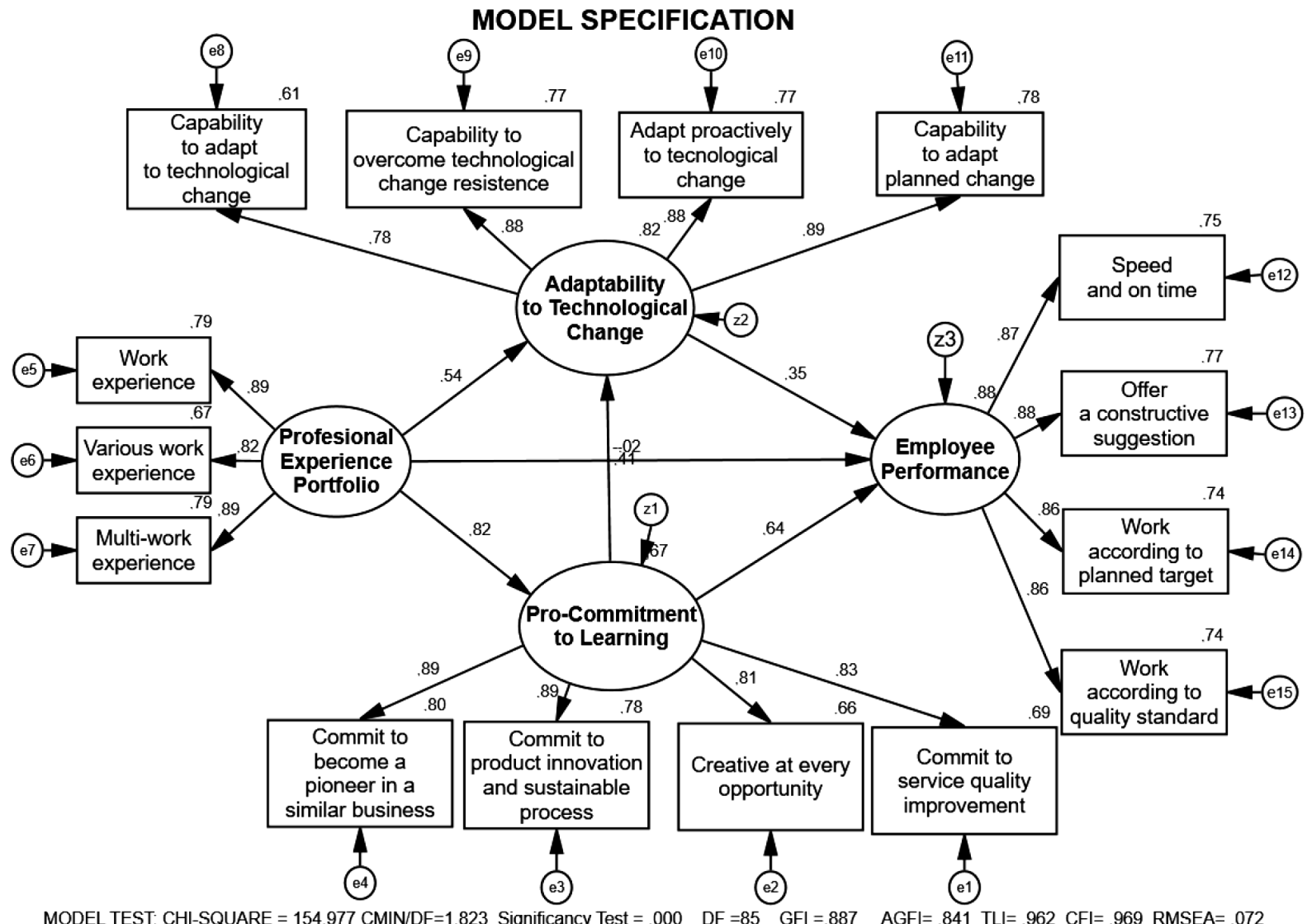

MODEL TEST: CHI-SQUARE $=154,977 \mathrm{CMIN} / \mathrm{DF}=1,823$ Significancy Test $=, 000 \quad \mathrm{DF}=85 \quad \mathrm{GFI}=, \mathbf{8 8 7} \quad \mathrm{AGFI}=, 841 \mathrm{TLI}=, 962 \mathrm{CFI}=, 969 \mathrm{RMSEA}=, 072$

Figure 1. The result of the research 
Table 4. Line test results coefficient: professional experience portfolio, pro-commitment to learning, adaptability to technological change, employee performance

\begin{tabular}{|c|l|c|c|c|l|}
\hline $\begin{array}{c}\text { Hypo- } \\
\text { thesis }\end{array}$ & & $\begin{array}{c}\text { Standar- } \\
\text { dized path } \\
\text { coefficients }\end{array}$ & t value & Prob. & \multicolumn{1}{|c|}{ Result } \\
\hline H1 & Adaptability to technological change $\rightarrow$ Employee performance & 0.380 & 2.762 & 0.006 & Significant \\
\hline H2 & Pro-commitment to learning $\rightarrow$ Adaptability to technological change & 0.378 & 4.091 & $* * *$ & Significant \\
\hline H3 & Pro-commitment to learning $\rightarrow$ Employee performance & 0.637 & 5.978 & $* * *$ & Significant \\
\hline H4 & Professional experience portfolio $\rightarrow$ Adaptability to technological change & 0.510 & 5.273 & $* * *$ & Significant \\
\hline H5 & Professional experience portfolio $\rightarrow$ Pro-commitment to learning & 0.842 & 11.030 & $* * *$ & Significant \\
\hline H6 & Professional experience portfolio $\rightarrow$ Employee performance & -0.020 & -0.173 & 0.863 & Not significant \\
\hline
\end{tabular}

- H2: there is an effect of pro-commitment to learning towards adaptability to technological change. Table 4 shows the path of structural models that explain the relationship between pro-commitment to learning towards adaptability to technological change. The structural path findings indicate that there is a significant relationship between pro-commitment to learning and adaptability to technological change $(\mathrm{t}=$ $4.091>1.96)$ with significant value $(0.00<0.01)$. So, the second hypothesis is accepted.

- H3: there is an effect of pro-commitment to learning toward employee performance. Table 4 shows the path of structural models that explain the relationship between pro-commitment to learning towards employee performance. The structural path findings indicate that there is a significant relationship between pro-commitment to learning and employee performance $(t=5.978>1.96)$ with significant value $(0.00<0.01)$. So, the third hypothesis is accepted.

- H4: there is an effect of professional experience portfolio towards adaptability to technological change. Table 4 shows the path of structural models that explain the relationship between professional experience portfolio towards adaptability to technological change. The structural path findings indicate that there is a significant and positive relationship between professional experience portfolio and adaptability to technological change $(t=5.296>1.96)$ with significant value $(0.00<0.01)$. So, the fourth hypothesis is accepted.

- H5: there is an effect of professional experience portfolio toward pro-commitment to learning. Table 4 shows the path of structural models that explain the relationship between professional experience portfolio toward pro-commitment to learning. The structural path findings indicate that there is a significant relationship between professional experience portfolio and pro-commitment to learning $(\mathrm{t}=11.030>$ $1.96)$ with significant value $(0.00<0.01)$. So, the fifth hypothesis is accepted.

- H6: there is an effect of professional experience portfolio toward employee performance. Table 4 shows the path of structural models that explain the rela- tionship between professional experience portfolio toward employee performance. The structural path findings indicate that there isn't significant relationship between professional experience portfolio and employee performance $(\mathrm{t}=-0.173<1.96)$ with significant value $(0.863>0.01)$. So, the sixth hypothesis isn't accepted.

- Based on the results of the sobel test, the statistical test shows a value of 6.21415511 , with a p-value of 0.000 which is significant at the 0.01 significance level. The mediating role of pro-commitment to learning on the influence of professional experience portfolio on employee performance is significant. This study concludes that pro-commitment to learning is able to mediate the influence of professional experience portfolio on employee performance. Since the direct influence of the portfolio professional experience on employee performance is negative and not significant, pro-commitment to learning serves as a full mediating variable.

- The role of mediation adaptation capability to technological change on the influence of professional portfolio experience on employee performance is also significant. Based on the results of the sobel test, the statistical test shows the value of 4.65566640 , with probability values both one-way and two-way less than 0.01 . Therefore, this study concludes that adaptation capability to technological change is able to fully mediate the effect of professional portfolio experience on employee performance.

The result of hypothesis testing shows that there is an effect of adaptation to technological change toward employee performance. The company has strengthened its core competence by adopting information technology. Therefore, it is important to understand how investment in technology contributes to business achievement. This is in line with the research by Lee et al. (2016) which says that wireless technology has the most significant influence in increasing business profit. Jabbouri et al. (2016) share the opinion that information technology infrastructure and innovation performance play an important role. On the information technology resources of companies, Bharadwaj (2000) argues that a company can be distinguished 
from other companies because of its ability to adopt technological changes. The company uses information technology to serve its specific needs, to renew the system, and to have competitive superiority that cannot be imitated by competitors. Companies develop new technologies to support consumer-oriented activities and eventually gain financial superiority due to increased profit.

This is in line with the role of pro-commitment to learning, which encourages employees' adaptation to new technology. A study by Tippins and Sohi (2003) shows perspectives on why some companies fail to achieve their expected profit, despite significant investment in information technology. The result of the study shows that the use of information technology needs support from competent employees through the creation of continuous organizational learning so that technological change and adaptation can increase efficiency.

The findings are in line with Sahi et al. (2019) superior performance can be achieved by companies through innovation and the willingness of organizations to deal with business risks, besides the influence of technology turbulence also gives a significant but negative impact, so it is concluded that superior performance will be achieved by organizations when technological turbulence tends to be low, medium competitive intensity is high. In line with the views of Morland and Pettersen (2018), however, changes in technological devices are highly dependent on people's readiness to deal with them. These findings reinforce the role of humans in technological change is dominant. In line with the theorist concept that redesigned modern technology can improve work effectiveness, and broader studies also emphasize the role of technology in initiating productivity and managing performance.

The result of this research shows that the professional experience portfolio has a significant effect on pro-commitment to learning. Cross-field experience gives more learning opportunity to supervisors and managers. Crossfield experience may not have a direct correlation with present tasks, but it gives supervisors and managers more experience that is useful for future organizational development, and for wider networking. The empirical results also support this view, as indicated by the highest score in the cross-field sector. Cross-field experience increases employees' skills, especially technical skills, problem-solving skills, and operational skills (Samagaio \& Rodrigues, 2016). Employee expertise and competence are built within their role in the company through a variety of training strategies which stimulate employees to keep learning. This is in accordance with Maurer and Weiss (2010) who noted that the employees' commitment to ongoing learning gave them the ability to learn new things and to recognize their own strengths and weaknesses. In line with the findings of Sraha et al. (2020) that export commitments are able to mediate the influence of company experience and performance. This finding reinforces the important role of commitment to build a larger export market with a business model that is able to overcome export barriers. In line with the findings of Fu et al. (2020) corroborating the findings of this study that the experience of managing an amusement park will increase the commitment of visitors, by designing an amusement park that can create value for visitors and be able to immerse visitors to enjoy the place of entertainment optimally.

The results support the research of Stacho et al. (2019) showing that education and training are considered as a way for an organization to retain its best employees to continue to learn and develop themselves, and increase their competence. Learning organizations are considered as organizational capital for business development in the long term, increasing competitiveness and increasing the ability of organizations to adapt to external changes. The findings of this study are education and training must continue to be developed, especially regarding the role of the organization because not all organizations support training and career development of employees, most of which happens is that training and education are employeesown awareness to develop. But in general this research supports the role of training and education in encouraging employee adaptation to change and improving employee performance.

The results of the study are in line with the view Nguyen and Luu (2019) that organizational learning is the process of how employees learn new things from people in the organization so that it will affect employee work behavior, increase competence, develop new insights and ideas and will ultimately affect performance organizational. Transformational leadership becomes a locomotive for organizations to transfer and share knowledge to improve organizational performance. Besides that, transformational leadership also promotes a culture of change on an ongoing basis by strengthening organizational innovation and changing work behavior (Keyes \& Benavides, 2018).

In line with the findings Mishchuk et al. (2016) this research found that the implementation of knowledge management systems will create asset growth and increase employee reproduction. Knowledge management with knowledge creation, knowledge acquisition, knowledge transfer, encourages opportunities to achieve competitive advantage through productive and innovative superior resources. This means that the knowledge repository managed by the organization contributes to improving employee competence, encouraging creativity, making the organization a learning organization that will have an impact on added value, increasing market share and increasing company assets.

The research result here shows that the professional experience portfolio has a significant impact on adaptation capability to technological change. The research of Sony and Mekoth (2016) shows the difference between employees with high and low levels of experience in facing changes. Professional experiences help employees to adapt to technological changes, to proactively adjust to changes, to adjust to planned changes, and to use new technology, as expected by the company. According to Gulfi et al. 
(2015), professional experience stimulates better, more effective and efficient systems. Poon and Brownlow (2014) further add that professional experience helps employees adapt to cheaper digital technologies and improve service. Professional knowledge and experience are essential in equipping employees to learn and adapt to new situations. To cope with rapid changes in the business environment, it is important that employees continue learning and practicing so that they can become proficient in the particular skills needed to perform their roles effectively. Basically, employees' capability to develop their career through ongoing learning and improving their levels of professionalism will stimulate them to adapt to various future changes and cope with more difficult challenges in their jobs (Murphy et al., 2006).

\section{Conclusions, research implications and research limitations}

The result shows that there is a significant positive effect of professional experience portfolio on pro-commitment to learning and on adaptability to technological change. The result also shows that there is a significant positive effect of commitment to learning and adaptability to technological change on employee performance. However, there is no significant influence of professional experience portfolio on performance. Both pro-commitment to learning and adaptability to technological change are both able to fully mediate the influence of the professional experience portfolio on performance.

An important finding from this study is that the portfolio of professional experience has the strongest impact on increasing the commitment to learning. Meanwhile, the best strategy is the role of the professional experience portfolio in encouraging pro-commitment to learning and improving employee performance. Theoretically, linear experience and cross-field experience dominate the understanding of the professional experience portfolio. The empirical results also support this view, which is indicated by the greatest value in linear experience and cross-field experience in increasing pro-commitment to learning.

The implication of this research is that the company is expected to be able to focus on improving linear experience by developing soft skills, technical skills and service improvement that are in line with the business goals of PT. POS. In addition, the company is expected to also enhance the experience of cross-cutting managers / supervisors, because PT POS's business focus is not only serving freight forwarding, but has expanded to broader services such as; financial services, property services and also retail. This study is expected to increase pro-commitment to learning, which is demonstrated by sustainable commitment to create progress by innovating in superior service, providing ideas for improvement and making the company a leader in the POS and courier services business. Pro-commitment to learning is done by increasing the involvement of managers / supervisors in the company's strategic decisions, providing space for regular and ongoing discussion, and giving authority according to their tasks. Managers and supervisors play the role of middle managers, so they have a close relationship with employees and also strategic partners for policy makers (superiors). Managers / supervisors understand the business on a strategic / policy level as well as technical / field, so that in facing changes and development of business cores that tend to be dynamic, they are at the forefront of the company.

The limitations of this study only use one analysis unit, PT Pos Indonesia, area VI, Yogyakarta and Central Java which is engaged in services, which has the same characteristics and objects, so this research has limitations in generalization. In the future, this research can be developed in various organizational analysis units or fields. In approving the research design data used is a cross section, it is hoped that further research can be used to use a longitudinal research design.

\section{Acknowledgements}

Acknowledgments we convey to DIKTIS (Director of Islamic Religious Higher Education) Ministry of Religion of the Republic of Indonesia, which has provided research assistance funds. We would like to convey our acknowledgment to the managers / supervisors of PT Pos Indonesia area VI Central Java and DIY who have been willing to provide secondary data, fill out questionnaires and conduct interviews.

\section{Research funding}

This research was conducted with full funding from the Directorate of Islamic Higher Education (DIKTIS) Directorate General of Islamic Education, Ministry of Religion of the Republic of Indonesia, number: Dt. I. IV/2/PP.00.9/ 1285/2014 and DJ.I/Dt.I.IV/4/ Hm.00.1/3011/2015 Determination of Recipients of Aid for Improving Qualifications of Educators and Education Personnel of S2 / S3 Education Completion Assistance (BPP) for Fiscal Year 2014 and 2015, and the research was completed in year 2018 .

\section{Contributions}

Fitri Wulandari: Contributes to the initial concepts and ideas of research in the form of research proposals. In addition to conducting full research on field research and conducting a total review of the final results of the study. Christantius Dwiatmadja: Contributes to designing relevant theories in research, conducting in-depth study of theories and building models and hypotheses by reviewing previous studies. Imronudin: Contributes to data processing and describe data and be present in discussions, conclusions and research implications. 


\section{References}

Argote, L. (2011). Organizational learning research: past, present and future. Management Learning, 42(4), 439-446. https://doi.org/10.1177/1350507611408217

Argyris, C., \& Schon, D. (1978). Organizational learning: A theory of action approach. Addision Wesley.

Bazin, Y., \& Aubert-Tarby, C. (2013). Dressing professional, an esthetic experience of professions. Society and Business Review, 8(3), 251-268.

https://doi.org/10.1108/SBR-04-2013-0031

Bharadwaj, A. S. (2000). A resource-based perspective on information technology capability and firm performance: an empirical investigation. MIS Quarterly, 24(1), 169-196. https://doi.org/10.2307/3250983

Bolatan, G. I. S., Gozlu, S., Alpkan, L., \& Zaim, S. (2016). The impact of technology transfer performance on total quality management and quality performance. Procedia-Social and Behavioral Sciences, 235, 746-755. https://doi.org/10.1016/j.sbspro.2016.11.076

Borgia, C. R., Siegel, P. H., \& Ortiz, D. (2014). A survival analysis of tax professionals' performance and internship experience. Accounting Research Journal, 27(3), 266-285. https://doi.org/10.1108/ARJ-04-2013-0018

Brzeziński, S., \& Bąk, A. (2015). Management of employees' commitment in the process of organization transformation. Procedia Economics and Finance, 27(15), 109-115. https://doi.org/10.1016/S2212-5671(15)00979-X

Buil, I., Martínez, E., \& Matute, J. (2019). Transformational leadership and employee performance: the role of identification, engagement and proactive personality. International Journal of Hospitality Management, 77, 64-75. https://doi.org/10.1016/j.ijhm.2018.06.014

Chang, P.-C., \& Chen, S.-J. (2011). Crossing the level of employee's performance: HPWS, affective commitment, human capital, and employee job performance in professional service organizations. The International Journal of Human Resource Management, 22(4), 883-901.

https://doi.org/10.1080/09585192.2011.555130

Eshlaghy, A. T., Maatofi, A., \& Branch, G. (2011). Learning orientation, innovation and performance: evidence from smallsized business firms in Iran. European Journal of Social Sciences, 19(1), 114-122.

Fu, X., Kang, J., \& Wiitala, J. J. H. J. (2020). Investigating the consequences of theme park experience through the lenses of self-congruity and flow. International Journal of Contemporary Hospitality Management, 32(3), 1181-1199. https://doi.org/10.1108/IJCHM-06-2019-0522

Glaub, M. E., Frese, M., Fischer, S., \& Hoppe, M. (2014). Increasing personal initiative in small business managers or owners leads to entrepreneurial success: A theory-based controlled randomized field intervention for evidence-based management. Academy of Management Learning \& Education, 13(3), 354-379. https://doi.org/10.5465/amle.2013.0234

Gonzalez, R. V. D., \& de Melo, T. M. (2018). The effects of organization context on knowledge exploration and exploitation. Journal of Business Research, 90, 215-225. https://doi.org/10.1016/j.jbusres.2018.05.025

Gulfi, A., Heeb, J.-L., Castelli Dransart, D. A., \& Gutjahr, E. (2015). Professional reactions and changes in practice following patient suicide: what do we know about mental health professionals' profiles? The Journal of Mental Health Training, Education and Practice, 10(4), 256-267.

https://doi.org/10.1108/JMHTEP-11-2014-0034
Hair, J. F., Anderson, R. E., Babin, B. J., \& Black, W. C. (2010). Multivariate data analysis: A global perspective (Vol. 7). Pearson Upper Saddle River, NJ.

He, J. (2014). Technology adoption in hospitals - the roles of system integration and technology support. In AMCIS 2014 Proceedings, 1-9.

Hooper, D., Coughlan, J., \& Mullen, M. (2008). Structural Equation Modelling: guidelines for determining model fit. Electronic Journal of Business Research Methods, 6(1), 53-60.

Jabbouri, N. I., Sirona, R., Zahari, I., \& Khalida, M. (2016). Impact of information technology infrastructure on innovation performance: an empirical study on private Universities in Iraq. Procedia Economics and Finance, 39, 861-869. https://doi.org/10.1016/S2212-5671(16)30250-7

Keyes, L. M., \& Benavides, A. D. (2018). Chaos theory, uncertainty, and organizational learning: what the Ebola incident in Dallas teaches us about organizations. International Journal of Organization Theory \& Behavior, 21(4), 226-241. https://doi.org/10.1108/DLO-08-2019-0177

Khojamli, M., Habibi, M., Hossein, M., \& Kazemiyan, M. (2014). The relationship between work experience, motivation, training and stress with labor productivity. Kuwait Chapter of the Arabian Journal of Business and Management Review, 3(11a), 31-35. https://doi.org/10.12816/0018778

Kumar, M., Chengappa, S., \& Pandya, S. (2013). Capability development: enhancing employee potential through strategic competency building and people development. International Journal of Management and Social Sciences Research, 2(2), 27-32.

Lee, H., Choi, H., Lee, J., Min, J., \& Lee, H. (2016). Impact of IT investment on firm performance based on technology IT architecture. Procedia Computer Science, 91, 652-661. https://doi.org/10.1016/j.procs.2016.07.164

Mahony, D. M., Klimchak, M., Morrell, D. L., Hill, R., \& Carolina, S. (2012). The portability of career-long work experience propensity to trust as a substitute for valuable work experience. Career Development International, 17(7), 606-625. https://doi.org/10.1108/13620431211283779

Mandal, S. (2017). An empirical competence-capability model of supply chain resilience. International Journal of Disaster Resilience in the Built Environment, 8(2), 190-208. https://doi.org/10.1108/IJDRBE-02-2015-0003

Maurer, T. J., \& Weiss, E. M. (2010). Continuous learning skill demands: associations with managerial job content, age, and experience. Journal of Business and Psychology, 25, 1-13. https://doi.org/10.1007/s10869-009-9126-0

Mishchuk, H., Bilan, Y., \& Pavlushenko, L. (2016). Knowledge management systems: issues in enterprise human capital management implementation in transition economy. Polish Journal of Management Studies, 14(1), 163-173. https://doi.org/10.17512/pjms.2016.14.1.15

Morland, C., \& Pettersen, I. J. (2018). Translating technological change-new technology and practices in a hospital. International Journal of Productivity and Performance, 67(6), 10001015. https://doi.org/10.1108/IJPPM-08-2016-0157

Muafi, Suwitho, Purwohandoko, \& Salsabil, I. (2018). Human capital in Islamic Bank and its effect on the improvement of healthy organization and employee performance. International Journal for Quality Research, 11(4), 849-868.

Murphy, C., Cross, C., Mcguire, D., Murphy, C., Cross, C., \& Mcguire, D. (2006). The motivation of nurses to participate in continuing professional education in Ireland. Journal of European Industrial Training, 30(5), 365-384. https://doi.org/10.1108/03090590610677926 
Nguyen, N. P., Evangelista, F., \& Kieu, T. A. (2019). The contingent roles of perceived budget fairness, budget goal commitment and vertical information sharing in driving work performance. Journal of Asian Business andEconomic Studies, 26(1), 98-116. https://doi.org/10.1108/JABES-06-2018-0026

Nguyen, T. T. N., \& Luu, T. M. N. (2019). Linking transformational leadership and organizational performance: an empirical investigation of manufacturing firms in Vietnam. Economics and Sociology, 12(2), 170-191.

https://doi.org/10.14254/2071-789X.2019/12-2/10

Omar, S., \& Noordin, F. (2016). Moderator influences on individualism-collectivism and career adaptability among ICT professionals in Malaysia. Procedia Economics and Finance, 37, 529-537. https://doi.org/10.1016/S2212-5671(16)30161-7

Park, K., \& Koh, J. (2017). Exploring the relationship between perceived pace of technology change and adoption resistance to convergence products. Computers in Human Behavior, 69, 142-150. https://doi.org/10.1016/j.chb.2016.12.017

Poon, J., \& Brownlow, M. (2014). Competency expectations for property professionals in Australia. Journal of Property Investment \& Finance, 32(3), 256-281. https://doi.org/10.1108/JPIF-12-2013-0068

Pousa, C., Mathieu, A., \& Trépanier, C. (2017). Managing frontline employee performance through coaching: does selling experience matter? International Journal of Bank Marketing, 35(2), 220-240. https://doi.org/10.1108/IJBM-01-2016-0005

Pudjiarti, E. S., \& Hutomo, P. T. P. (2020). Innovative work behaviour: an integrative investigation of person-job fit, personorganization fit, and person-group fit. Business: Theory and Practice, 21(1), 39-47. https://doi.org/10.3846/btp.2020.9487

Razak, A. R. A., Othman, A. A., \& Sundram, V. P. K. (2015). The relationships of human success factor, information technology, and procurement process coordination on operational performance in building construction industry - a proposed conceptual framework. Procedia Economics and Finance, 31, 354-360. https://doi.org/10.1016/S2212-5671(15)01209-5

Rong, S., Hou, S., \& Cheng, C. W. (2012). Outside director experience, compensation, and performance. Managerial Finance, 38(10), 914-936. https://doi.org/10.1108/03074351211255146

Saadat, V., \& Saadat, Z. (2016). Organizational learning as a key role of organizational success. Procedia - Social and Behavioral Sciences, 230, 219-225.

https://doi.org/10.1016/j.sbspro.2016.09.028

Sahi, G. K., Gupta, M. C., Cheng, T. C. E., \& Lonial, S. C. (2019). Relating entrepreneurial orientation with operational responsiveness: Roles of competitive intensity and technological turbulence. International Journal of Operations \& Production Management, 39(5), 739-766.

https://doi.org/10.1108/IJOPM-07-2018-0411
Samagaio, A., \& Rodrigues, R. (2016). Human capital and performance in young audit firms. Journal of Business Research, 69(11), 5354-5359.

https://doi.org/10.1016/j.jbusres.2016.04.137

Samnani, A., Singh, P., \& Ezzedeen, S. (2013). Workplace bullying and employee performance: an attributional model. Organizational Psychology Review, 3(4), 337-359. https://doi.org/10.1177/2041386613475370

Sony, M., \& Mekoth, N. (2016). The relationship between emotional intelligence, frontline employee adaptability, job satisfaction and job performance. Journal of Retailing and Consumer Services, 30, 20-32. https://doi.org/10.1016/j.jretconser.2015.12.003

Sraha, G., Sharma, R. R., Crick, D., \& Crick, J. M. (2020). International experience, commitment, distribution adaptation and performance: a study of Ghanaian firms in B2B export markets. Journal of Business \& Industrial Marketing, 35(11). https://doi.org/10.1108/JBIM-05-2019-0197

Stacho, Z., Stachová, K., \& Raišienè, A. G. (2019). Change in approach to employee development in organizations on a regional scale. Journal of International Studies, 12(2), 299-308. https://doi.org/10.14254/2071-8330.2019/12-2/19

Stensaker, I. G., \& Meyer, C. B. (2012). Change experience and employee reactions: developing capabilities for change. Personnel Review, 41(1), 106-124. https://doi.org/10.1108/00483481211189974

Tajeddini, K. (2016). Analyzing the influence of learning orientation and innovativeness on performance of public organizations: the case of Iran. Journal of Management Development, 35(2), 134-153. https://doi.org/10.1108/JMD-03-2015-0033

Tien, H. L. S., Wang, Y. C., Chu, H. C., \& Huang, T. L. (2012). Career adapt-abilities scale-Taiwan form: psychometric properties and construct validity. Journal of Vocational Behavior, 80(3), 744-747. https://doi.org/10.1016/j.jvb.2012.01.010

Tippins, M. J., \& Sohi, R. S. (2003). IT competency and firm performance: is organizational learning a missing link? Strategic Management Journal, 24(8), 745-761. https://doi.org/10.1002/smj.337

Woo, H. (2018). New CEOs' previous experience and acquisition performance. International Journal of Organizational Analysis, 27(3). https://doi.org/10.1108/IJOA-03-2018-1389

Zappa, P., \& Robins, G. (2015). Organizational learning across multi-level networks. Social Networks, 44, 295-306. https://doi.org/10.1016/j.socnet.2015.03.003 